Agro-Science Journal of Tropical Agriculture, Food, Environment and Extension Volume 16 Number 3 (September 2017) pp. 23 - 28

ISSN 1119-7455

\title{
PROXIMATE COMPOSITION, TOTAL PHENOL CONTENT AND SENSORY PROPERTIES OF SWEET BASIL (OCIMUM BASILICUM L.) LEAVES DRIED USING DIFFERENT METHODS
}

\author{
Akah, N.P. Eze, K. and Omah, E.C. \\ Department of Food Science and Technology, University of Nigeria, Nsukka. \\ *nkechi.akah@unn.edu.ng
}

\begin{abstract}
O. basilicum L. samples were sun dried (SUD), solar dried (SOD), shade dried (SD) and oven-dried at $50^{\circ} \mathrm{C}, 60^{\circ} \mathrm{C}, 70^{\circ} \mathrm{C}$ and $80^{\circ} \mathrm{C}\left(\mathrm{OV}_{5}-\mathrm{OV}_{8}\right.$, respectively). The samples were evaluated for proximate composition, polyphenol content, soluble extract, appearance, aroma and general acceptability. Fresh sample served as the control. All the drying methods reduced the moisture levels of the samples to that $(<12 \%)$ suitable for shelf stability, and led to significantly $(p<0.05)$ higher content of protein, ash and crude fiber in dried samples. The polyphenol content of water extract of dried samples ( $1.55 \mathrm{mg} \mathrm{GAE} / 100 \mathrm{ml}$ in $\mathrm{OV}_{5}$ to $2.25 \mathrm{mg} G A E / 100 \mathrm{ml}$ in $O V_{6}$ ) were significantly (p<0.05) higher than that of fresh sample $(1.13 \mathrm{mg} G A E / 100 \mathrm{ml})$ and those of $S U D, O V_{5}$ and $O V_{8}$ were significantly $(p<0.05)$ lower than that of $\mathrm{OV}_{6}$. Sample $\mathrm{OV}_{6}$ was higher in water and ethanol soluble extracts $(69 \%$ and $61 \%$, respectively) than the fresh sample $(37 \%$, respectively) and the other dried samples (16-37\% and 2-19\%, respectively). The scores of the dried samples for appearance (5.15 in SUD to 6.40 in $\mathrm{OV}_{6}$ ), aroma (5.30 in SUD to 6.85 in $\mathrm{OV}_{6}$ ) and general acceptability (5.10 in $\mathrm{OV}_{5}$ to 7.25 in $\left.\mathrm{OV}_{8}\right)$ were significantly $(p<0.05)$ lower than those of the fresh sample $(8.65,8.45$ and 8.55 , respectively). The aroma score for $O V_{6}(6.85)$ was significantly $(p<0.05)$ higher than the aroma scores for $\mathrm{OV}_{5}$, SUD, $\mathrm{SOD}$ and $\mathrm{SD}$ (5.30-5.55). Oven drying at $60^{\circ} \mathrm{C}$ was identified as the best drying method for $O$. basilicum in terms of aroma and soluble extracts contents.
\end{abstract}

Keywords: $O$. basilicum, sensory attributes, drying methods, physicochemical Properties

\section{INTRODUCTION}

Ocimum basilicum L. (sweet basil) belongs to the Lamiaceae family and is a popular culinary herb with highly aromatic leaves that has a pleasant and vigorous flavor (Di-Cesare et al., 2003; Sullivan, 2009). The leaves and their essential oils are both used as flavoring agents. Linalool (44.18\%), 1, 8-cineole (13.65\%), eugenol $(8.59 \%)$, methyl cinnamate $(4.26 \%)$, isocaryophyllene $(3.10 \%)$ and $\alpha$-cubebene $(4.97 \%)$ are the main flavor components (Loughrin and Kasperbauer, 2003; Ismail, 2006; Soković et al., 2007; NurzyńskaWierdak et al., 2012). Sweet basil is native to Africa and Asia and today exists in a number of varieties varying in size, color and flavor. They range from large to dwarf forms, tinyleafed to large succulent leaves which could be green, purple, or variegated (Sullivan, 2009). Sweet basil is one of the most important herbs to many cultures and cuisine. It is used in many vegetable, meat and fish dishes, sauces, stews, dressings, herbal teas, liqueurs, and mixed drinks, and frequently as complimentary flavor to tomatoes (Sullivan, 2009). It also has several medicinal uses and strong antimicrobial activities against pathogenic bacteria, virus and fungi which are attributed mainly to its bioactive compounds: terpenes and polyphenols. It has been used as a folk remedy for an enormous number of ailments, including boredom, cancer, convulsion, deafness, diarrhea, epilepsy, gout, impotency, insanity, nausea, toothaches, and respiratory diseases including whooping cough (Ismail, 2006; Soković et al., 2007; Sullivan, 2009; Rocha et al., 2011; Efterpi et al., 2012). Basil is also rich in basic nutrients - vitamins and minerals, especially calcium (177 mg/100 g), iron $(3.17 \mathrm{mg} / 100 \mathrm{~g})$, magnesium (64 mg/100 $\mathrm{g})$, phosphorus (56 mg/100 g), potassium (295 $\mathrm{mg} / 100 \mathrm{~g})$, vitamin A (5275 IU), and vitamin $\mathrm{K}(415 \mu \mathrm{g} / 100 \mathrm{~g})$ (USDA, 2013).

In Nigeria, basil is usually grown in home gardens, and can be used fresh or dry. However, it is mostly used and enjoyed fresh by many, especially in flavoring rice dishes

Please cite as: Akah, N.P. Eze, K. and Omah, E.C.(2017). Proximate composition, total phenol content and sensory properties of sweet basil (ocimum basilicum 1.) leaves dried using different methods. Agro-Science, 16 (3), 23-28. DOI: https://dx.doi.org/10.4314/as.v16i3.4 
and tomato-based sauces and stews. Fresh $O$. basilicum has low keeping quality and is scarce during some seasons of the year limiting its availability and use. For these reasons, attempts are made locally by people to sun-dry it for later use. Drying reduces water activity, inhibits microbial, biological and chemical degradation reactions, and consequently improves stability of products. It is judged the most commonly used method for enhancing the shelf life of leafy vegetables and aromatic/medicinal plants. However, drying, especially sun drying also affects the sensory and nutritional characteristics of products, promoting the collapse of vegetable tissue, degradation of vital nutrients, and reduction of predominant flavors (Di-Cesare et al., 2003; Loughrin and Kasperbauer, 2003; Sullivan, 2009; Rocha et al., 2011; Anonymous, 2013). Different drying methods have been reported to produce varying quality of dried products. It was recommended that the drying process be as quickly as possible, at temperature levels which do not drive off the volatile flavor compounds. The drying temperature regime was in addition shown to be specific to each crop (Di-Cesare et al., 2003; UNIDO/FAO, 2005; Antal et al., 2011; Rocha et al., 2011).

There is paucity of data in literature relating the adequate drying method(s) and/or temperature for $O$. basilicum. Identifying the method of drying among the common drying methods that produces high quality dried $O$. basilicum is worthwhile. This study, therefore, aimed at evaluating the effect of different drying methods (sun, solar, shade and oven) on the sensory and some chemical properties of Ocimum basilicum L. sourced from Nsukka locality and consequently identifying the most suitable drying method.

\section{MATERIALS AND METHODS}

Fresh plants of $O$. basilicum L. (Figure 1) were obtained from a farm at Odenigwe in Nsukka Local Government Area of Enugu State, at the early hours of the morning. The plant was authenticated by a taxonomist in the Department of Plant Science and Biotechnology, University of Nigeria, Nsukka. The leaves were washed, drained and weighed into $200 \mathrm{~g}$ portions each for drying. Fresh leaves served as control. Sun, solar drier, shade and oven drying were used to obtain the dried samples. Oven drying was carried out at four temperature regimes $-50^{\circ} \mathrm{C}, 60^{\circ} \mathrm{C}, 70^{\circ} \mathrm{C}$, and $80^{\circ} \mathrm{C}$. The plant was solar- dried using a solar tent obtained from the Department of Food Science and Technology, University of Nigeria, Nsukka. Eight samples were obtained in all. The dried samples for analysis were milled into flour, packaged in polyethelene bags and stored in an airtight container. Fresh samples for analysis were periodically harvested from the same farm. Proximate composition was determined according to the method of AOAC (2010).

\section{Determination of water and ethanol soluble extracts}

Ethanol and water soluble extracts of fresh and dried $O$. basilicum were determined using the method described by Pearson (1976) with some modifications (Dent et al., 2013). A 5g portion each of fresh and dried sweet basil powder was blended with $100 \mathrm{ml}$ of water and $100 \mathrm{ml}$ of $30 \%$ ethanol, respectively. The mixture was shaken thoroughly and allowed to stand at room temperature for 48 hours. Afterwards, the mixtures were filtered using a What-man filter paper (No1). The filtrate (20 $\mathrm{ml}$ ) was respectively evaporated to dryness in small beakers in an oven at $105^{\circ} \mathrm{C}$ and the amount of water and ethanol extracts respectively calculated and expressed as a percentage of the original sample weight as follows:

Percentage $(\%)$ yield of extract $=$ Weight of extract (g) / Weight of sample $(\mathrm{g}) \times 100$ $=$ Weight of extract per aliquot $(\mathrm{g}) \times$ total $\underline{\text { volume of extract }(\mathrm{ml}) \times \quad \underline{100}}$

volume of aliquot $(\mathrm{ml})$ weight of sample $(\mathrm{g})$ Where aliquot of extract or volume of aliquot= $20 \mathrm{ml}$.

\section{Determination of total phenol content}

Total phenol content of the water and ethanol extracts were respectively determined using the Folin-Ciocalteu method of Singleton and Rossi (1965). A $1 \mathrm{ml}$ volume of extract solution (filtrates from above) was pipette into test tubes and made up to $5 \mathrm{ml}$ with distilled water. Then, $0.5 \mathrm{ml}$ of Folin-Ciocalteu reagent was added and the content of each test tube mixed thoroughly. The mixture was left to stay for 5 minutes after which $2 \mathrm{ml}$ of $20 \% \mathrm{Na}_{2} \mathrm{CO}_{3}$ was added and the volume made up to $10 \mathrm{ml}$ with distilled water, mixed properly and allowed to stand for 30 minutes before the absorbance was taken at $760 \mathrm{~nm}$ using a UV/Vis spectrophotometer. Results were calculated as garlic acid equivalent (mg GAE/ $\mathrm{ml}$ ) by interpolating on the standard phenol curve.

Sensory evaluation was carried out on the fresh and dried leaves using 20-man panel of judges from the Department of Food Science and Technology, University of Nigeria Nsukka. Attributes evaluated were appearance, aroma and general acceptability. A 9-point 
Hedonic scale was used in the evaluation, with 9=like extremely and 1=sdislike extremely.

\section{Data analysis}

Experiment was laid out in a completely randomized experimental design (CRD). Analysis of variance was done using SPSS 16.0 version software. Results were presented as mean \pm standard deviation and Duncan's Multiple Range Test was used for mean separation. Significant difference among sample means was accepted at $\mathrm{p}<0.05$.

\section{RESULTS AND DISCUSSION \\ Proximate composition}

Table 1 shows the proximate composition of fresh and dried samples of $O$. basilicum. All the drying methods efficiently reduced the moisture level of the dried samples (9.20$11.40 \%)$ to that $(\leq 12 \%)$ reported to be adequate for shelf stability (up to one year) for dry vegetables (Rocha et al., 2011; Anonymous, 2013). Drying also led to higher protein (15-18\%), ash (12-15\%) and crude fiber $(9-11 \%)$ in comparison to the protein $(5 \%)$, ash $(2 \%)$ and crude fiber $(0.7 \%)$ contents of the fresh sample. Anonymous (2013) noted that drying concentrated nutrients in vegetables, thereby increasing the quantity per unit weight. The author is also of the view that leaf powder can be used to correct malnutrition or prevent it in vulnerable people by adding it to basic recipes including cookies, cakes, pasta, biscuits, among others. Dried $O$. basilicum may therefore serve as enrichment material in products such as baked goods where these nutrients are usually lacking.

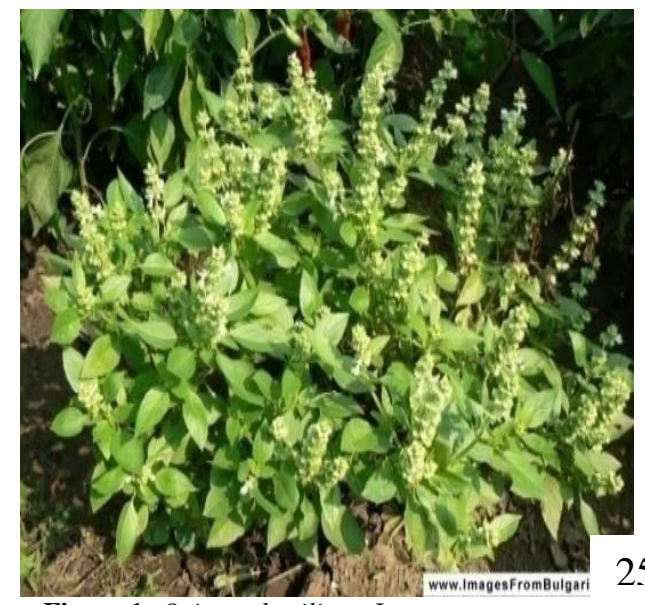

Figure 1: Ocimum basilicum L.

Polyphenol content
Table 2 shows the polyphenol content and the water- and ethanol-soluble extracts of the fresh and dried $O$. basilicum samples. The polyphenol content of water extract of dried $O$. basilicum samples $(1.55 \mathrm{mg} \mathrm{GAE} / 100 \mathrm{ml}$ in $\mathrm{OV}_{5}$ to $2.25 \mathrm{mg} \mathrm{GAE} / 100 \mathrm{ml}$ in $\mathrm{OV}_{6}$ ) were significantly $(\mathrm{p}<0.05)$ higher than that of fresh O. basilicum $(1.13 \mathrm{mg} \mathrm{GAE} / 100 \mathrm{ml}$ ) but those of samples sun-dried (SUD), oven-dried at $50^{\circ} \mathrm{C}\left(\mathrm{OV}_{5}\right)$ and oven-dried at $80^{\circ} \mathrm{C}\left(\mathrm{OV}_{8}\right)$ were significantly $(\mathrm{p}<0.05)$ lower than that of sample oven-dried at $60^{\circ} \mathrm{C} \quad\left(\mathrm{OV}_{6}\right)$. The polyphenol content of ethanol extract of shade dried sample $(2.04 \mathrm{mg}$ GAE/100 ml) was significantly $(p<0.05)$ higher than those of other dried samples $(1.25 \mathrm{mg}$ GAE/100 $\mathrm{ml}$ in $\mathrm{OV}_{5}$ to $1.58 \mathrm{mg} \mathrm{GAE} / 100 \mathrm{ml}$ in $\mathrm{OV}_{8}$ ) and that of fresh sample $(1.0 \mathrm{mg} \mathrm{GAE} / 100 \mathrm{ml})$ but that of fresh sample did not differ significantly ( $p>0.05$ ) from those of sun, solar and $50^{\circ} \mathrm{C}$ oven-dried samples.

The lower polyphenol content of fresh sample was generally attributed to high moisture level of the fresh samples. The generally higher polyphenol content of water extracts of the samples compared with the ethanol extracts was attributed to high polarity or water solubility of $O$. basilicum polyphenols. Polarity of polyphenols has been found to determine their solubility in the extracting solvent and consequently their yield (Dent et al., 2013). Tiwari et al. (2011) reported that during extraction, solvents diffuse into the solid plant material and solubilize compounds with similar polarity; and Dent et al. (2013) observed that polarities of polyphenols ranged from polar to non polar, thus eliciting a wide range of solvents (water, acetone, methanol, ethanol among others) for their extraction, while Proestos et al. (2008) reported that polyphenols were generally water soluble because they often occurred as glycosides. It is, therefore, plausible to say that high polarity of $O$. basilicum polyphenol resulted in higher solubility and consequently higher extraction yield in water which is more polar than aqueous ethanol. Water extract of henna leaves was similarly found to contain higher polyphenol content than the methanol extract (Haddad and Dezashibi, 2007). On the contrary, aqueous ethanol was found the most suitable solvent system for the extraction of sage polyphenols due to the different polarities of their polyphenols (Dent et al., 2013). 
Proximate Composition, Total Phenol Content and Sensory Properties of Sweet Basil

Table 1: Proximate composition of fresh and dried O. basilicum L. samples (\%)

\begin{tabular}{lllllll}
\hline Samples & Moisture & Fat & Protein & Crude fiber & Ash & Carbohydrate \\
\hline SUD & $9.20^{\mathrm{b}} \pm 0.00$ & $1.50^{\mathrm{a}} \pm 0.00$ & $16.43^{\mathrm{b}} \pm 0.00$ & $9.95^{\mathrm{c}} \pm 0.00$ & $14.15^{\mathrm{f}} \pm 0.00$ & $48.75^{\mathrm{c}} \pm 0.02$ \\
SD & $9.35^{\mathrm{b}} \pm 0.07$ & $1.65^{\mathrm{c}} \pm 0.00$ & $18.45^{\mathrm{d}} \pm 2.12$ & $10.50^{\mathrm{h}} \pm 0.01$ & $14.60^{\mathrm{g}} \pm 0.00$ & $45.44^{\mathrm{b}} \pm 2.07$ \\
SOD & $11.40^{\mathrm{c}} \pm 0.07$ & $1.60^{\mathrm{b}} \pm 0.00$ & $17.20^{\mathrm{b}} \pm 0.00$ & $10.30^{\mathrm{g}} \pm 0.01$ & $14.70^{\mathrm{h}} \pm 0.00$ & $44.79^{\mathrm{b}} \pm 0.02$ \\
OV5 & $11.21^{\mathrm{c}} \pm 0.01$ & $1.97^{\mathrm{d}} \pm 0.03$ & $18.20^{\mathrm{c} d} \pm 0.00$ & $9.36^{\mathrm{c}} \pm 0.01$ & $13.64^{\mathrm{d}} \pm 0.05$ & $45.61^{\mathrm{b}} \pm 0.12$ \\
OV6 & $11.40^{\mathrm{c}} \pm 0.00$ & $2.22^{\mathrm{e}} \pm 0.00$ & $18.20^{\mathrm{cd} \pm 0.00}$ & $9.45^{\mathrm{d}} \pm 0.00$ & $13.31^{\mathrm{c}} \pm 0.01$ & $45.41^{\mathrm{b}} \pm 0.02$ \\
OV7 & $8.55^{\mathrm{a}} \pm 0.00$ & $3.55^{\mathrm{g}} \pm 0.00$ & $18.10^{\mathrm{cd}} \pm 0.02$ & $10.10^{\mathrm{f}} \pm 0.00$ & $13.89^{\mathrm{e}} \pm 0.01$ & $45.79^{\mathrm{b}} \pm 0.04$ \\
OV8 & $9.20^{\mathrm{b}} \pm 0.00$ & $3.51^{\mathrm{f}} \pm 0.01$ & $15.92^{\mathrm{b}} \pm 0.00$ & $9.16^{\mathrm{b}} \pm 0.01$ & $12.01^{\mathrm{b}} \pm 0.01$ & $50.19^{\mathrm{c}} \pm 0.04$ \\
Fresh & $85.80^{\mathrm{d}} \pm 0.42$ & $1.97^{\mathrm{d}} \pm 0.00$ & $4.80^{\mathrm{a}} \pm 0.01$ & $0.68^{\mathrm{a}} \pm 0.01$ & $1.57^{\mathrm{a}} \pm 0.04$ & $5.17^{\mathrm{a}} \pm 0.50$ \\
\hline
\end{tabular}

Values are means of duplicate determination \pm standard deviation. Means with same superscript within the same column are not significantly different at $(\mathrm{p}>0.05) . \mathrm{SUD}=$ sun dried sample, $\mathrm{SD}=$ shed dried sample, $\mathrm{SOD}=\mathrm{solar}$ dried sample, $\mathrm{OV} 5=0 \mathrm{oven}$ dried at $50^{\circ} \mathrm{C}$, $\mathrm{OV} 6=$ oven dried at $60^{\circ} \mathrm{C}, \mathrm{OV} 7=$ oven dried at $70^{\circ} \mathrm{C}, \quad \mathrm{OV} 8=$ oven dried at $80^{\circ} \mathrm{C}$.

Table 2: Total phenol content, water and ethanol soluble extracts of fresh and dried $O$. basilicum L.

\begin{tabular}{llllll}
\hline Samples & $\begin{array}{l}\text { Total pehnol content } \\
\text { of water extract } \\
(\mathrm{mg} \mathrm{GAE} / \mathrm{ml})\end{array}$ & $\begin{array}{l}\text { Total pehnol content } \\
\text { extract }(\mathrm{mg} \mathrm{GAE} / \mathrm{ml})\end{array}$ & $\begin{array}{l}\text { of ethanol } \\
\text { extracts }(\%)\end{array}$ & $\begin{array}{l}\text { Water } \\
\text { soluble }\end{array}$ & $\begin{array}{l}\text { Ethanol } \\
\text { extracts }(\%)\end{array}$ \\
\hline SUD & $1.83^{\mathrm{bc}} \pm 0.02$ & $1.44^{\mathrm{ab}} \pm 0.02$ & $31.32^{\mathrm{bc}}$ & $17.05^{\mathrm{cd}}$ \\
SD & $1.97^{\mathrm{cc}} \pm 0.00$ & $2.04^{4^{\mathrm{c}} \pm 0.52}$ & $37.37^{\mathrm{b}}$ & $9.14^{\mathrm{e}}$ \\
SOD & $2.02^{\mathrm{cd}} \pm 0.09$ & $1.47^{\mathrm{ab}} \pm 0.11$ & $15.73^{\mathrm{e}}$ & $19.49^{\mathrm{c}}$ \\
OV5 & $1.55^{\mathrm{b}} \pm 0.02$ & $1.25^{\mathrm{ab}} \pm 0.02$ & $23.11^{\mathrm{d}}$ & $19.05^{\mathrm{c}}$ \\
OV6 & $2.25^{\mathrm{d}} \pm 0.07$ & $1.51^{\mathrm{b}} \pm 0.02$ & $68.85^{\mathrm{a}}$ & $60.91^{\mathrm{a}}$ \\
OV7 & $2.01^{\mathrm{cd}} \pm 0.01$ & $1.54^{\mathrm{b}} \pm 0.02$ & $21.64^{\mathrm{d}}$ & $19.49^{\mathrm{c}}$ \\
OV8 & $1.83^{\mathrm{bc}} \pm 0.07$ & $1.58^{\mathrm{b}} \pm 0.02$ & $25.24^{\mathrm{cd}}$ & $2.44^{\mathrm{f}}$ \\
Fresh & $1.13^{\mathrm{a}} \pm 0.39$ & $1.00^{\mathrm{a}} \pm 0.05$ & $36.72^{\mathrm{b}}$ & $36.55^{\mathrm{b}}$
\end{tabular}

Values are means of duplicate determination \pm standard deviation. Means with same superscript within the same column are not significantly different at $(\mathrm{p}>0.05) . \mathrm{SUD}=$ sun dried sample, $\mathrm{SD}=$ shed dried sample, $\mathrm{SOD}=$ solar dried sample, $\mathrm{OV} 5=\mathrm{oven}$ dried at $50^{\circ} \mathrm{C}, \mathrm{OV} 6=$ oven dried at $60^{\circ} \mathrm{C}, \mathrm{OV} 7=$ oven dried at $70^{\circ} \mathrm{C}, \mathrm{OV} 8=$ oven dried at $80^{\circ} \mathrm{C}$.

Table 3: Scores for appearance, aroma and general acceptability of samples of fresh and dried Ocimum basilicum

\begin{tabular}{llll}
\hline Samples & Appearance & Aroma & General acceptability \\
\hline SUD & $5.15^{\mathrm{a}} \pm 1.42$ & $5.30^{\mathrm{a}} \pm 1.65$ & $5.25^{\mathrm{a}} \pm 1.91$ \\
SD & $6.15^{\mathrm{a}} \pm 1.69$ & $5.40^{\mathrm{a}} \pm 1.93$ & $5.15^{\mathrm{a}} \pm 2.00$ \\
SOD & $6.45^{\mathrm{a}} \pm 2.18$ & $5.55^{\mathrm{a}} \pm 2.11$ & $5.15^{\mathrm{a}} \pm 2.05$ \\
OV5 & $5.35^{\mathrm{a}} \pm 2.36$ & $5.55^{\mathrm{a}} \pm 2.08$ & $5.10^{\mathrm{a}} \pm 2.26$ \\
OV6 & $6.40^{\mathrm{a}} \pm 2.20$ & $6.85^{\mathrm{b}} \pm 1.56$ & $5.45^{\mathrm{a}} \pm 2.01$ \\
OV7 & $5.85^{\mathrm{a}} \pm 1.95$ & $6.05^{\mathrm{ab}} \pm 1.98$ & $5.85^{\mathrm{a}} \pm 2.41$ \\
OV8 & $6.35^{\mathrm{a}} \pm 1.89$ & $6.05^{\mathrm{ab}} \pm 2.28$ & $7.25^{\mathrm{b}} \pm 2.35$ \\
Fresh & $8.65^{\mathrm{b}} \pm 0.48$ & $8.45^{\mathrm{c}} \pm 0.60$ & $8.55^{\mathrm{c}} \pm 0.51$ \\
\hline
\end{tabular}

Values are means of duplicate determination \pm standard deviation. Means with same superscript within the same column are not significantly different at $(\mathrm{p}>0.05)$. $\mathrm{SUD}=$ sun dried sample, $\mathrm{SD}=$ shed dried sample, $\mathrm{SOD}=$ solar dried sample, $\mathrm{OV} 5=\mathrm{Oven}$ dried at $50^{\circ} \mathrm{C}$, OV6 $=$ oven dried at $60^{\circ} \mathrm{C}, \mathrm{OV} 7=$ oven dried at $70^{\circ} \mathrm{C}, \mathrm{OV} 8=$ oven dried at $80^{\circ} \mathrm{C}$.

The higher polyphenol content of water extract of $O$. basilicum oven-dried at $60^{\circ} \mathrm{C}$ was similarly observed in sage leaves extracted with different solvents at temperatures of $60^{\circ} \mathrm{C}$ and $90^{\circ} \mathrm{C}$. Optimal polyphenol yield of dry sage leaves was observed at $60^{\circ} \mathrm{C}$. This was attributed to increased solubility and reduced degradation of active compounds at this temperature (Rocha et al., 2011; Dent et al., 2013). The yields of water- and ethanol-soluble extracts of samples dried at $60^{\circ} \mathrm{C}(68.85 \%$ and $60.91 \%$, respectively) were significantly $(\mathrm{p}<0.05)$ higher than the yield of water- and ethanolsoluble extracts of the fresh sample $(36.72 \%$ and $36.55 \%$, respectively) and those of the other dried samples (15.73-37.37\% and $2.44-19.49 \%$, respectively). The yields of water-soluble extracts of the samples were generally higher than the yields of their ethanol-soluble extracts. The high yield observed in extracts of samples oven dried at $60^{\circ} \mathrm{C}$ was attributed to gentle disruption of cell walls at this temperature, but without cell damage, for easier penetration of solvents to the cellular membrane to extract the intracellular ingredients from the plant material.

Temperature has repeatedly been listed as a key factor that affected quantity and composition of extracts among other factors such as type of solvent, solvent concentration, polarity of extracted compounds and particle size of material for extraction (Tiwari et al., 2011). The lower yield of soluble extracts of samples oven dried at higher temperatures of $70^{\circ} \mathrm{C}$ and $80^{\circ} \mathrm{C}$ were attributed to degradation, oxidation and/or polymerization of components such as polyphenols at these elevated temperatures (Rocha et al., 2011; 
Dent et al., 2013). Compounds such as polyphenols according to Dent et al. (2013) are susceptible to oxidation and degradation from high temperature and alkaline environment. The low yield of soluble extracts for SUD, $\mathrm{SOD}, \mathrm{SD}$ and $\mathrm{OV}_{5}$ could be attributed to enzymatic breakdown or hydrolysis of susceptible components due to prolonged drying period of up to 4 days. According to Tiwari et al. (2011), the polyphenol oxidase caused degradation of polyphenols under favorable conditions. Demir et al. (2004), UNIDO/FAO (2005) and Anonymous (2013) also reported that longer drying time (at low temperature) gave microbes and enzymes more time to destroy susceptible components before the leaves were fully dried. The generally higher yield of water soluble extracts of the samples was attributed to high polarity of compounds of $O$. basilicum resulting in higher solubility and consequently higher extraction yield in water which is more polar than aqueous ethanol (Tiwari et al., 2011; Dent et al., 2013).

\section{Sensory scores}

The sensory scores of the samples are presented in Table 3. The scores for appearance (8.65), aroma (8.45) and general acceptability (8.55) for fresh $O$. basilicum were significantly $(p<0.05)$ higher than the scores for appearance (5.15 in SUD to 6.40 in $\mathrm{OV}_{6}$ ), aroma (5.30 in SUD to 6.85 in $\mathrm{OV}_{6}$ ) and general acceptability (5.10 in $\mathrm{OV}_{5}$ to 7.25 in $\mathrm{OV}_{8}$ ) for the dried samples. The score for aroma for the sample oven dried at $60^{\circ} \mathrm{C}(6.85)$ was significantly $(\mathrm{p}<0.05)$ higher than that of the sample oven dried at $50^{\circ} \mathrm{C}(5.55)$ and those dried using sun (5.30), solar (5.55) and shade (5.40). The lower scores for appearance and aroma in the dried $O$. basilicum samples were respectively attributed to breakdown of chlorophyll pigment and losses in aroma compounds during drying (Di-Cesare et al., 2003; Loughrin and Kasperbauer, 2003; Antal et al., 2011; Rocha et al., 2011). Di-Cesare et al. (2003) reported that during drying the desirable green chlorophyll pigment in fresh $O$. basilicum was degraded to brown colored pheophytin pigment due to the loss of $\mathrm{Mg}^{2+}$ while Loughrin and Kasperbauer (2003) and Antal et al. (2011) reported up to 50-fold decrease and $43 \%$ loss in the concentration of volatile compounds in fresh $O$. basilicum and spearmint leaves, respectively, as a result of drying.

The lower aroma scores for the sample oven dried at $50^{\circ} \mathrm{C}$ and those dried using sun, solar and shade relative to the aroma score for the sample oven dried at $60^{\circ} \mathrm{C}$ was attributed to higher loss of volatile aromatic compounds from these samples due to longer drying time which exacerbated higher enzymatic activity. Rocha et al. (2011) reported that longer drying time of Taxus baccata at $30^{\circ} \mathrm{C}$ resulted in higher enzymatic activity, degradation and very low yield of its main aromatic compound, taxol. They also reported higher loss of essential volatile aromatic compounds in Cymbopogon winterianus dried at $30^{\circ} \mathrm{C}, 40^{\circ} \mathrm{C}, 50^{\circ} \mathrm{C}$ and $70^{\circ} \mathrm{C}$ relative to the sample of Cymbopogon winterianus dried at $60^{\circ} \mathrm{C}$ while Di-Cesare et al. (2003) reported better retention of color and flavor in $O$. basilicum dried at $60^{\circ} \mathrm{C}$. Dwivedy et al. (2012) also observed a similar result in a medicinal Indian Borage (Coleus aromaticus) leaves dried at the temperature regimes of 50$80^{\circ} \mathrm{C}$ using hot air drying. The study proposed drying the leaves of Indian Borage at $60^{\circ} \mathrm{C}$ in hot air dryer in order to obtain an acceptable product.

These literatures showed that drying at a temperature of $60^{\circ} \mathrm{C}$ preserved quality of many aromatic and medicinal herbs especially in terms of their appearance and flavor/aroma. Aroma may be considered the most important sensory attribute in spices and herbs since they are primarily used to impart flavor to food. Appearance is also desirable especially in fresh herbs, although it is often lost in fresh $O$. basilicum during cooking. O. basilicum ovendried at $60^{\circ} \mathrm{C}$ may, therefore, serve as a good substitute for the fresh ones in culinary uses as it appeared there was least degradation of the aroma/flavor compounds of $O$. basilicum at this temperature.

\section{CONCLUSION}

Drying led to lower scores in the sensory attributes of the dried samples; however, their scores were also generally high in comparison to those of the fresh sample. Sample ovendried at $60^{\circ} \mathrm{C}$ showed the highest score for aroma among the dried samples, with a score close to that of the fresh sample. Sample oven dried at $60^{\circ} \mathrm{C}$ also contained higher polyphenol and soluble extracts than the other dried samples. All the drying methods reduced the moisture levels of the samples to that suitable for shelf stability and led to significantly $(p<0.05)$ higher content of protein, ash and crude fiber in dried samples. Oven drying at $60^{\circ} \mathrm{C}$ was found to favor the samples more than the other drying methods in the qualities evaluated. It was, therefore, identified as the drying method most suitable for $O$. basilicum. 


\section{REFERENCES}

Anonymous (2013). Drying leaf vegetables. Available from http://www.leafforlife.org/assets/downloads/Ch08 -21stCentGreens.pdf. Accessed August 27, 2013.

Antal, T., sKerekes, B. and Sikolya, L. (2011). Influence of drying on the volatile compounds of spearmint (Mentha spicata L.). In: Proceedings of the III European Drying Conference EuroDrying, 2011.Available from http://www.uibcongres.org/imgdb/archivo_dpo11 058.pdf. Accessed December 17: 2017.

AOAC (2010). Official Methods of Analysis (18 ${ }^{\text {th }}$ ed.), Association of Official Analytical Chemists, Washington D. C., USA.

Demir, V., Gunhan, T., Yagcioglu, A.K. and Degirmencioglu, A. (2004). Mathematical modelling and the determination of some quality parameters of air-dried bay leaves. Biosystems Engineering, 88: (3), 325-335.

Dent, M., Dragovic-Uzelac, V., Penic, M., Brncic, M., Bosiljkov, T. and Levaj, B. (2013). The effect of extraction solvents, temperature and time on the composition and mass fraction of polyphenols of dalmatian wild sage (Salvia officinalis L.). Food Technol. Biotechnol., 51:(1), 84-91.

Di-Cesare, L.F., Forni, E., Viscardi, D. and Nani, R.C. (2003). Changes in the chemical composition of basil caused by different drying procedures. Journal of Agricultural and Food Chemistry, 51:(12), 3575-3581.

Dwivedy, S., Rayaguru, K. and Sahoo, G.R. (2012). Effect of drying methods on quality characteristics of medicinal Indian borage (Coleus aromaticus) leaves. J. Food Process Technol., 3:(11), 1-6.

Efterpi, C., Bonos, E., Giannenas, I. and FlorouPaneri, P. (2012). Aromatic plants as a source of bioactive compounds. Agriculture, 2: 228-243.

Haddad, K.M.H. and Dezashibi, Z. (2007). Phenolic compounds and antioxidant activity of henna leaves extracts (Lawsonia Inermis). World $J$. Dairy and Food Sci., 2: (1): 38-41.

Ismail, M. (2006). Central Properties and Chemical Composition of Ocimum basilicum Essential Oil. Pharmaceutical Biology, 44: (8), 619-626.

Loughrin, J.H. and Kasperbauer, M.J. (2003). Aroma content of fresh basil (Ocimum basilicum L.) leaves is affected by light reflected from colored mulches. Journal of Agricultural and Food Chemistry, 5: 2272-2276.

Nurzyńska-Wierdak, R., Bogucka-Kocka, A., Kowalski, R. and Borowski, B. (2012). Changes in the chemical composition of the essential oil of sweet basil (Ocimum basilicum L.) depending on the plant growth stage. Chemija, 23: (3), 216-222.

Pearson, D. (1976). The Chemical Analysis of Foods ( $7^{\text {th }}$ ed.), Churchill Livingstone, London and New York, p. 292.

Proestos, C., Boziaris, I.S., Kapsokefalou, M. and Komaitis, M. (2008). Natural antioxidant constituents from selected aromatic plants and their antimicrobial activity against selected pathogenic microorganisms. Food Technol. Biotechnol., 46:(2): 151-156.

Rocha, R.P., Melo, E.C. and Radünz, L.L. (2011). Influence of drying process on the quality of medicinal plants: A review. Journal of Medicinal Plants Research, 5:(33), 7076-7084.

Singleton, V.L. and Rossi, J.A. (1965). Colorimetry of total phenolic substances. American Chemical Society Symposium Series, 26: 47-70.

Soković, M., Marin, P.D., Brkić, D. and vanGriensven, L.J.L.D. (2007). Chemical composition and antibacterial activity of essential oils of ten aromatic plants against human pathogenic bacteria. Food 1: (1), 1-7.

Sullivan, C. (2009). Herbs. Available from http://academics.hamilton.edu/foodforthought/Ou r_Research_files/herbs.pdf Accessed August 13, 2013.

Tiwari, P., Kumar, B., Kaur, M., Kaur, G. and Kaur, H. (2011). Phytochemical screening and extraction: A Review. Internationale Pharmaceutica Sciencia, 1:(1), 98-106.

UNIDO/FAO (2005). Herbs, spices and essential oils: Post-harvest operations in developing countries. Available from http://www.unido.org/fileadmin/user_media/Publi cations/Pub_free/Herbs_spices_and_essential_oil s.pdf. Accessed August 13: 2013.

USDA (2013). National Nutrient Database for Standard Reference Release 26. Available fromhttp://ndb.nal.usda.gov/ndb/foods/show/268 Accessed August 27:2013. 